Rizoma freireano • Rhizome freirean - n. 13 • 2012 • Instituto Paulo Freire de España

\title{
Lifelong learning and \\ Schools as Community Learning Centres: Key aspects of a National Curriculum Draft Policy Framework for Malta
}

Peter Mayo

University of Malta

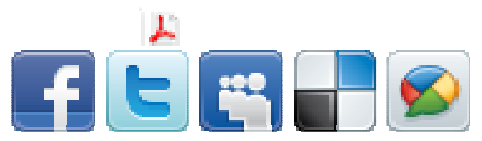

The island of Malta has been engaged in policy document formulations for curriculum renewal in the country's educational system (4-16 years of age) since 1988 when the first National Minimum Curriculum (henceforth NMC) was launched (Wain, 1991; Borg et al, 1995). In 1999 a revamped NMC (Ministry of Education, 1999) was developed following a long process of consultation involving various stages and stakeholders. It was a compromise document (Borg \& Mayo, 2006) which emerged as a result of reactions to a more radical and coherent draft document produced in 1988.

Both curricular documents were subject to debates and critiques (Wain, 1991; Darmanin, 1993; Borg et al, 1995; Giordmaina, 2000; Borg and Mayo, 2006). More recently a series of volumes providing guidelines, key principles and aims for a national curriculum framework (henceforth NCF) have been produced (MEEF, 2011a,b,c,d) and are currently the target of debate and the focus of reactions by various stakeholders in education including teachers who were asked to read the volumes and provide reactions in the form of answers to a set questionnaire. In this paper, I will focus on one aspect of the documents, the first of its three aims: 'Learners who are capable of successfully developing their full potential as lifelong learners.' It is that aspect of the framework documents that falls within the purview of the title for this special issue. The use of this notion attests to the influence of the EU's policy communications on member states, Malta having joined the Union in 2004 (Mayo, 2007).

The NCF documents base their vision for the future of education in Malta around the now widespread concept of Lifelong learning in keeping with the dominant discourse which has emerged from not only the EU but also the OECD. One notices the discursive shift from the old UNESCO discourse on lifelong education (Tuijnman, A and BostrÖm, 2002). Much has been written about this discourse from a critical perspective (Murphy, 2007; Williamson, 1998; Brine, 1999; Wain, 2004; Borg \& Mayo, 2005, Field, 2001, 2010), to make policy makers aware of the shift in emphasis that has occurred from the broad, humanistic concept of Lifelong Education (Faure et al, 1972) to that of Lifelong 
Learning. This shift is not innocent and ties in with some of the hegemonic ideas that are often taken on board uncritically without the slightest concern for the kind of ideology that underpins such terminology. It is felt that one needs to eschew the current meanings attributed to the notion of Lifelong Learning if one is to engage in a commitment to education for social justice.

The dominant discourse on lifelong learning, as adopted in the NCF, is one that shifts the onus of responsibility onto the individual rather than the state and the social collectivity. Learning and adequate provision for it become a matter of individual rather than social responsibility. This is all in keeping with the politics of responsibilisation that is hegemonic these days, shifting the responsibility for learning onto individuals and communities. (Darmanin, 2011)

\section{Collective Dimension of Learning}

In contexts such as these, a reversal to the old UNESCO discourse of Lifelong Education would help only if we avoid the rather individualistic orientation of some (not all) of the relevant writings and follow those writings that place emphasis on not only the individual but also the collective dimensions of learning as indicated in passim by Dave (1976) and more in depth by Bogdan Suchodolski (1976), Williamson (1998), Gelpi (2002), Walters et al (2004), Livingstone \& Sawchuk (2004), Borg \& Mayo, (2005) and Wain (2004). Related concepts such as lifewide learning and the learning society have often (not always) been developed within the context of a vision for collective learning in addition to individual learning, especially in the literature just cited.

While criticality is mentioned in the NCF documents, as a component of a genuine process of lifelong learning, a key point in the above literature, this has not been spelt out. There is an emphasis on "solving problems."(MEEF, 2011b, p. 28) This sounds quite fair. However, the question that arises is whether learning entails more than this. Is it just a matter of solving problems with the mistaken belief that there is a clear answer to any question raised? What about handling complexity? What about problem- posing in addition to problem solving? Surely, a genuine study of literature at the later stages of secondary education should help drive this point home. Confining oneself to the latter (problem solving) could lead to the emergence of very resourceful people, including a pool of technocrats, while the former can serve the purpose of developing a healthy democracy with people serving as social actors and not atomized individuals who simply embody certain attributes and are attuned to acting in ways that allow them to be governed indirectly and by proxy, what Foucault would call governmentality.

The documents (MEEF, 2011b) place emphasis on the imagination, defined, following Ken Robinson and Lou Aronica (2009), as "the capacity for original thought" with creativity meaning "applied imagination." (MEEF, 2011b, p.28). This is a welcome development in the dominant Maltese policy discourse. And it is imperative that approaches to teaching/learning are imaginative and involve the constant arousal of 'epistemological curiosity,' as Freire (1998) would put it. Unless this occurs schools would be providing little in the way of creating the right milieu for lifelong learners, both 
individually and collectively. Boring and mind numbing teaching can either put off students from wanting to learn formally and possibly non formally or alternatively make them seek alternative sources of knowledge as a reaction to formal schooling, part and parcel of a 'counter culture' (which has frequently been the case with some but not all). Developing a counter-discourse and culture is not necessarily a bad thing and has been a survival strategy for several artists, writers, dissidents and other intellectuals. It would however serve to underline a dissonance between conventional schooling and the emancipatory or self-creative (individual and collective) aspirations of its students.

The notion of students as lifelong learners also has implications for guidance and counseling (Sultana, 2003). Guidance and counseling needs to be broadened to become a lifelong learning service. The officials involved also need to treat persons as lifelong learners. This is in keeping with one of the better six key messages of the EU's Memorandum on Lifelong Learning (CEC, 2001). The objective of Message 5 is to "Ensure that everyone can easily access good quality information and advice about learning opportunities throughout Europe and throughout their lives." (CEC, 2001, 17) This message is of great importance for countries in Europe that still restrict guidance and counseling facilities to schools and tertiary institutions, as well as public and private labor market agencies. Given the variegated and broad nature of the field of education, comprising the formal and non-formal (mentioned in the NCF documents) sectors, not to mention informal learning, a holistic and lifelong approach to guidance and counseling is being advocated in European Commission documents (Sultana, 2003). The net result of this strategy at the European level is that more and more Guidance and Counseling provisions are meant to follow citizens throughout life; enhance social inclusion by engaging reluctant learners in educational and training experiences; present up-to-date information that responds to people and employer needs; network with NGOs (though care is cautioned here given the onset of too much ' ngoisation', in these days of 'neoliberalism', in lieu of proper and socially committed state intervention) to address specific needs; and avail oneself of the potential of technology-based infrastructures for guidance and counseling purposes (Sultana, 2003).

The notion of conceiving of students as lifelong learners also has implications for evaluation (Skager, 1978). What do we evaluate? Do we evaluate simply possession and mastery of skills and knowledge, important and crucial in light of learners' entitlement as citizens in a democratic country or also the ability to explore and identify new forms of knowledge and insights? In the latter case, this would mean venturing beyond the knowledge provided in the classroom by crossing borders in the manner explained by Young $(1998,2004)$ with regard to his proposed notion of a mix between in depth learning of core areas characterized by 'strong framing', in Basil Bernstein's terms, and trans-disciplinary areas. This is intended towards the goal of enabling lifelong learners to take charge, both individually and collectively, of their own learning especially in future.

The school contributes little to lifelong learning if it produces 'failures ' who have not learned or achieved from school the skills, knowledge and further learning networks to which they are entitled as citizens. Certain core areas have to be mastered by all. One must be aware of the pitfalls indicated by Gramsci (1971) and others with regard to the 
adoption of watered down progressivist ideas. Active learning is important but also entails rigor and mastery of certain skills. While anchoring pupils learning in strong disciplinary knowledge (Young, 2004), the school can pave the way, in the later years, for improvisation by encouraging students to venture beyond the 'comfort zone' of such knowledge by crossing boundaries. One requires the right balance between disciplinary cross-borders and in depth knowledge, with strong a 'framing' and 'classification' of certain disciplines such as Maths and the natural sciences, and a weaker 'classification' and 'framing' of others which are very closely related.

The idea of lifelong learning was consolidated, in the 1988 draft NMC and the 1999 final NMC document. when they promoted the idea of schools as community learning centres (SCLCs).

"Schools should serve as community learning centres that also cater for the adult members of the community. This principle combines the commitment of this Curriculum to a holistic education with the recognition of the importance of lifelong education and the need for stakeholder participation in the educational process."

\section{(Ministry of Education, 1999, p. 89)}

This idea remains a valid one and continues to be mentioned in the NCF especially with regard to parental involvement in schools. It should involve much more than simply parental involvement (as mentioned in the NCF documents), important though this aspect is. The SCLCs project should not however be dependent for its implementation on simply ESF (European Social Funds) funds which are intermittent (as was the case in Malta around 2005 with regard to the abortive funding of the short-lived community learning centres in different towns and villages) and are geared solely towards 'employability' which does not necessarily mean employment, as Ettore Gelpi (2002) once remarked.There is more to community learning than 'employability.' There is a need for indications regarding how the community can serve as a learning enhancing resource. The final document, for which this draft provides a basis for discussion, also needs to spell out the educational, democratic and economic reasons why we need to conceive of schools as community learning centres, a concept found in some of the literature on small states. Summing up this literature, I would submit that there are three arguments to be made

1. Democratic argument: Schools, especially state schools, are public resources. This proposed project constitutes an attempt to make democratic use of public resources.

2. Economic argument: The cost, per capita, of public resources in a micro-state such as Malta is higher than that incurred in larger states. One must make better and maximum use of resources, lest these resources become 'idle capital' for several hours during the day and entire months during the calendar year.

3. Educational argument(with regard to schooling): It is not only adult members of the community who benefit from such schools but also children. Links between schools and the community would create greater space for the involvement of 
more stakeholders, such as parents, in the school process. This would create closer ties between schools and their pupils' immediate home environment, without confining the latter to a ' campanilismo' style of education. On the contrary, there should be both a global and local dimension to the education provided, otherwise one would be restricting the children's different 'universes of knowledge.'

The work of Didacus Jules (2004) from St. Lucia, in the Caribbean, is instructive here. He helped develop a multipurpose learning school in Trinidad \&Tobago on the lines of a school as a community learning centre (Mayo et al, 2008, p.230). State funding is crucial for such a project which entails teachers' and heads' continuing professional development in this area (this is a crucial area in courses on educational administration and leadership). It also involves restructuring buildings to accommodate adults and building new schools as community learning centres from the very start. This entails liaison between the areas of education and architecture. It represents a new vision for schools born out of the reality of small jurisdictions, a vision that turns scale (Baldacchino, 2008) into a virtue rather than an impediment.

\section{Conclusion}

As a recent member of the European Union, Malta has been quick to embrace the notion of Lifelong learning which can be regarded as the Union's master concept for learning just as it was UNESCO's master concept for education in the past. This particular interpretation of lifelong learning within the EU policy context differs considerably from the more expansive notion used by UNESCO. Though contested within different epistemic communities within the EU, which must not be seen to be monolithic, the overarching notion that emerges from its main policy documents thus far (one awaits an overdue and revised document ten years after the launch of the EU Memorandum in 2001) is that of lifelong learning for employability and a narrowly defined notion of active citizenship which overlooks the collective dimension of education for social change and which provides a very problematic notion of individualized learning. This notion does not reflect any cognizance of the way concepts, assumptions and practices are influenced by mechanisms that prey on people's sensibilities. Any further development of the Maltese curriculum discourse should be predicated on an awareness of these mechanisms in the interest of providing guidelines for an education geared towards an enhancement of social justice. One hopes to see the overriding notion of lifelong learning for this proposed renewed curriculum fleshed out, in the final National Curriculum document, in a manner that takes on board some of the criticisms leveled at the current discourse emanating from the EU. One hopes that it would do this in the spirit of developing a more holistic approach to lifelong learning/education that eschews its reduction to simply matters of production and consumption and encourages an alternative conceptualization of persons as collectively and individually engaged social actors. Options for learning and living a full life would thus be broadened, while the basic necessary knowledge, to which every citizen is entitled, would be made available without any dilutions. 


\section{References}

Baldacchino, G (2010) 'Entrepreneurship on Smaller Jurisdictions: Appraising a Glocal Elite'in Mayo, P (Ed.) Education in Small States. Global Imperatives, Regional Initiatives and Local Dilemmas, London \& New York: Routledge.

Borg, C, Camilleri, J., Mayo, P. and Xerri, T. (1995), ' Malta's National Curriculum. A Critical Analysis’ in International Review of Education, Vol. 41, pp. 337-356.

Borg, C \& Mayo, P (2004) 'Diluted wine in new bottles. The key messages of the EU Memorandum on Lifelong Learning', Lifelong Learning in Europe (LlinE), Vol. 9 No. 1, pp. $19-25$

Borg, C \& Mayo, P (20060 Learning and Social Difference. Challenges for Public Education and Critical pedagogy, Boulder, Colorado: Paradigm.

Brine, J. (1999), Under educating Women: Globalizing Inequality, Milton Keynes: Open University Press).

Brown, P., Lauder, H., \& Ashton, D. (2010). The global auction. The broken promises of education, jobs, and incomes. New York: Oxford University Press.

CEC (2001), Commission Staff Working Paper. A Memorandum on Lifelong Learning, (Brussels, European Commission).

Darmanin, M. (1993), ' More things in heaven and earth: contradictions and co-optation in education policy' in International Studies in Sociology of Education, Vol. 3, pp. 147 167.

Darmanin, M (2011), ' A reading of the National Curriculum Framework 2011' powerpoint presentation to Department of Education Studies, University of Malta, Seminar on draft NCF documents, Corinthia San Gorg, Malta, Monday 4 July.

Dave, R.H. (1976), 'Foundations of Lifelong Education: Some Methodological Aspects' in Dave, R.H. (ed.), Foundations of Lifelong Education, Oxford, Pergamon Press; Hamburg: UNESCO Institute for Education.

Faure, E, Herrera, F., Kaddoura, A-R., Lopes, H., Petrovsky, A.V., Rahnema, M., Champion Ward, F. (1972), Learning to Be. The world of education today and tomorrow, Paris: UNESCO.

Field, J. (2001), 'Lifelong Education' in International Journal of Lifelong Education, Vol. 20, Nos. 1 and 2, pp. 3-15. 
Field, J. (2010) 'Lifelong learning' in P. Peterson, E. Baker, \& B. McGaw (Eds.), International encyclopedia of education ( ${ }^{\text {rd }}$ ed.). Amsterdam: Elsevier.

Freire, P. (1998b), Pedagogy of Freedom. Ethics, Democracy and Civic Courage, Lanham: Rowman \& Littlefield.

Gelpi, E. (2002), Lavoro Futuro. La formazione professionale come progetto politico, Milan: Edizioni Angelo Guerini e Associati SpA.

Giordmaina, J. (ed.) (2001), National Curriculum - Proceedings of a National Conference, June 2000, Malta: Publishers Enterprises Group.

Gramsci, A. (1971b), in Hoare, Q and Nowell Smith G (Eds.), Selection from the Prison Notebooks, New York: International Publishers.

Jules, D. (1994/5), 'Adult Education Policy in Micro-States. The Case of the Caribbean' in Policy Studies Review, Vol. 13, no. 3 and 4, pp. 415-432.

Livingstone, D.W. \& Sawchuk, P. (2004). Hidden knowledge: Organized labour in the information age, Toronto: Garamond Press; Lanham, MA: Rowman \& Littlefield.

Mayo, P (2007), Adult Education in Malta, Bonn: DVV International.

Mayo, P, Pace, P and Zammit, E (2008), 'Adult Continuing Education in Small States. The Case of Malta,' Comparative Education, Vol. 44, No.2, pp. 229-246.

Murphy, M. (1997), 'Capital, class and adult education: the international political economy of lifelong learning in the European Union,' in Armstrong, P, Miller, $\mathrm{N}$ and Zukas, M (Eds.), Crossing Borders. Breaking Boundaries: Research in the Education of Adults, Proceedings of the $27^{\text {th }}$ Annual SCUTREA Conference, London, Birkbeck College : University of London.

MEEF (2011a) Towards a Quality Education for All. The National Curriculum Framework Consultation Document 1 Executive Summary, Malta: Ministry of Education, Employment \& the Family.

MEEF (2011b) Towards a Quality Education for All. The National Curriculum Framework Consultation Document 2 Rationale and Components, Malta: Ministry of Education, Employment \& the Family.

MEEF (2011c) Towards a Quality Education for All. The National Curriculum Framework Consultation Document 3 The Three Cycles, Malta: Ministry of Education, Employment \& the Family.

MEEF (2011d) Towards a Quality Education for All. The National Curriculum Framework Consultation Document 4 The Way Forward, Malta: Ministry of Education, 
Employment \& the Family.

Ministry of Education (1999) Creating the Future Together. National Minimum Curriculum, Malta: Ministry of Education.

Parson, S. (1990), 'Lifelong learning and the community school' in Poster, C and Kruger, A. (Eds.), Community Education in the Western World, London and New York:

Routledge.

Robinson, K with Aronica, L (2009), The Element: How finding your passion changes everything. New York: Viking Penguin.

Skager, R. (1978), Lifelong Education and Evaluation Practice, Oxford: Pergamon Press.

Suchodolski, B. (1976), Lifelong Education - Some Philosophical Aspects, in: R.H. Dave (Ed.), Foundations of Lifelong Education, Oxford: Pergamon Press; Hamburg: UNESCO Institute for Education.

Sultana, R.G. (2003), Lifelong Guidance and the European Challenge. Issues for Malta, Malta: Euroguidance Malta.

Tuijnman, A \& Bostr Ö m, A-K (2002), 'Changing Notions of Lifelong Education and Lifelong Learning,' in International Review of Education, Vol. 48, Nos. 1/2, pp. 93-110.

Wain, K (1991) Malta's National Curriculum. A Critical Evaluation, Malta: Mireva.

Wain, K. (2004), The Learning Society in a Postmodern World, New York: Peter Lang.

Walters, S., Borg, C., Mayo, P and Foley, G. (2004), 'Economics, Politics and Adult Education, in Foley, G (Ed.), Dimensions of Adult Learning. Adult Education and Training in a Global Era, Sydney: Allen \& Unwin; London: McGraw Hill, Open University Press.

Williamson, B. (1998), Lifeworlds and Learning. Essays in the theory, philosophy and practice of lifelong learning, Leicester: NIACE.

Young, M.F.D. (1998), The Curriculum of the Future. From the 'new sociology of education' to a critical theory of learning, London: Falmer Press.

Young, M.F.D (2004) 'Curriculum studies and the problem of knowledge: updating the Enlightenment?' in Lauder, H., Brown, P., Dillabough, J.A. \& A. H. Halsey (EDS.) Education, Globalization and Social Change, Oxford, Oxford University Press. 